\title{
A questão indígena sob a ditadura militar: do imaginar ao dominar'
}

The indigenous quest under the military dictatorship: from imagining to dominating

\section{Carlos Benítez Trinidad}

\section{(2) OpenEdition}

\section{Journals}

Edição electrónica

URL: http://journals.openedition.org/aa/2986

DOI: 10.4000/aa.2986

ISSN: 2357-738X

\section{Editora}

Programa de Pós-Graduação em Antropologia Social (UnB)

\section{Edição impressa}

Data de publição: 1 julho 2018

Paginação: 257-284

ISSN: 0102-4302

\section{Refêrencia eletrónica}

Carlos Benítez Trinidad, «A questão indígena sob a ditadura militar: do imaginar ao dominar'», Anuário Antropológico [Online], v.43 n.1 | 2018, posto online no dia 26 maio 2019, consultado o 27 abril 2021. URL: http://journals.openedition.org/aa/2986 ; DOl: https://doi.org/10.4000/aa.2986

\section{(c) $($ ) $\odot \odot$}

Anuário Antropológico is licensed under a Creative Commons Atribuição-Uso Não-Comercial-Proibição de realização de Obras Derivadas 4.0 International. 


\title{
A questão indígena sob a ditadura militar: do imaginar ao dominar ${ }^{1,2}$
}

\author{
Carlos Benítez Trinidad
}

UFBA/UPO

\section{Introdução}

A fixação da Alteridade dentro do nosso próprio imaginário tem servido tradicionalmente para criar uma ordem cósmica que tem nos permitido outorgar significados manejáveis a nossa própria ontologia. Criar uma dicotomia em constante tensão fixa e também define nosso próprio papel existencial no universo, como oposição ou aproximação às alteridades que nos circundam. $\mathrm{O}$ etnocentrismo serve muito bem para dar sentido a nossa existência. Inventamos a nós mesmos como a "normalidade" do ser humano, reduzindo a significantes muito simples e ordenados, normalmente numa escala de valores autorreferencial, a realidade plural, infinita e, sobretudo, ameaçante que nos rodeia (limitação da qual não escapam nem os mesmos antropólogos que discorrem sobre o tema, como explica Viveiros de Castro no "Nativo Relativo", 2002).

A característica comum e universal deste atributo radica na autorrepresentação do nós como a humanidade "verdadeira", assim, dentro da escala autorreferencial, as alteridades mais vizinhas ou mais afastadas de nosso marco referencial simbólico gozam de mais ou menos humanidade, ao compartilhar certas características conosco. Viver em tensão com essas alteridades dão sentido pleno a nossa existência, e isso é visível em todas as dimensões possíveis à hora de necessitar nos definir.

Essa forma de compreender o mundo, tão simplificadora e conflituosa, é um dos lastros que o ser humano, como raça, não consegue superar, gerador de agitações e tensões constantes. Segundo Everardo Rocha (1984), o etnocentrismo é uma visão do mundo em que nosso próprio grupo é tomado como centro de tudo, e no qual todos os outros são pensados e sentidos através de nossos valores, nossos modelos e nossa definição do que é existir. O próprio pensador ressalta que o etnocentrismo é um fenômeno onde se misturam tanto "elementos intelectuais e racionais quanto elementos emocionais e afetivos", sendo, entre todos 
os fatores humanos, talvez, o de maior unanimidade. O choque que essa experiência gera nasce da constatação das diferenças ao observar e interatuar com o outro, processo que Rocha reproduz no seu expressivo "monólogo etnocêntrico":

Como aquele mundo de doidos pode funcionar? Espanto! Como é que eles fazem? Curiosidade perplexa? Eles só podem estar errados ou tudo o que eu sei está errado! Dúvida ameaçadora?! Não, a vida deles não presta, é selvagem, bárbara, primitiva! Decisão hostil! (Rocha, 1984)

Esse processo de comparação do "nós” com uma alteridade que ameaça nosso sistema de referências, pelo simples fato de existir e entender o mundo de maneira diferente acaba numa concorrência que sempre é ganha pelo "nós". Pois somos nós que fazemos as coisas "bem", de forma "natural” e, certo, com "superioridade", contra as outras cujas ações não fazem o menor sentido, são antinaturais e absurdas.

Certo, as fronteiras do etnocentrismo contêm um perigo inerente a sua própria existência, que é conceber aos pertencentes à alteridade, normalmente, como carentes de humanidade ou, ao menos, de não compartilhar nossa própria humanidade ou não ser totalmente humanos. Assim, o "nós" se constitui como o humano "verdadeiro" e o outro como um "não humano", ou um de natureza duvidosa. Os exemplos são tão variados e em tão grande quantidade como é plural o ser humano, desde etnias cujos nomes significam "homens de verdade" ou "a gente" até a própria antropologia ocidental, que demorou muito tempo para começar a questionar que o conceito de anthropos (humano) é uma construção cultural subjetiva e não um axioma universal.

Nesta perigosa semente do Outro com quem não se compartilha uma natureza similar, ao ser estranho a nossas referências, reside o eixo central desta exposição. Imaginar a alteridade que nos rodeia como uma oposição ou um estranho ao Nós, leva-nos a desenhar características que podem acabar facilitando a criação das lógicas que legitimam a dominação sobre o Outro, e a imposição de nossa ontologia "verdadeira” na forma de hegemonia. Esse é o passo que leva do imaginar ao dominar, e a partir daí normalizar através de exploração, subordinação ou eliminação, a violência física ou cultural sobre o Outro.

Dentro dessa lógica dicotômica do ser humano, temos que destacar, então, a proposta Euro-ocidental que tem liderado a hegemonia mundial desde a era dos descobrimentos, no final do século XV. O etnocentrismo europeu levou sua 
vocação de imperialidade universal de uma maneira exitosa, desde então, até meados do século XX, sobrevivendo a suas lógicas, certo, até hoje ${ }^{3}$. Durante todo esse tempo, se estabeleceu um mundo normalizado através da interpretação europeia (mais especificamente norte-europeia) da realidade, suas representações culturais, seu sistema de valores, suas referências simbólicas, etc. A vasta expansão de um etnocentrismo definido como um todo continental frente a um mundo plural, alheio, perigoso e explorável, deu como resultado uma realidade colonial que se enfrentava continuamente às tensões geradas pela dominação da Alteridade e a convivência com a mesma, dando passo a uma rica mestiçagem e sincretismo (Gruzinski, 2004).

Os maiores expoentes desta panela quente de enfrentamentos, negociação e dominação, são aquelas regiões colonizadas que começaram a mostrar os sintomas de uma esquizofrenia identitária desde a época colonial. Dita situação madurou com a criação dos Estados-nação emancipados das metrópoles europeias na primeira metade do século XIX. Estes viviam uma situação de desorientação referencial a causa do etnocentrismo supeditado à colonialidade (Maldonado-Torres, 2007) das elites, e que encheu de fortes tensões internas aquelas sociedades (traduzidas em racismo e suas desambiguações, como a desigualdade, a exclusão ou a marginalidade social, política e cultural), criando uma região, como é a América Latina do século XX, cheia dessas contradições herdadas de um etnocentrismo europeu colonialista e imperial, que negava sua própria mestiçagem e pluralidade nascida da assimilação e confrontação com as alteridades que povoavam aquelas terras.

Tendo o explicado até agora como quadro referencial, o qual vai continuar a ser detalhado durante o texto, o usaremos na pesquisa da situação da questão indígena no Brasil durante a ditadura civil-militar, que dominou o país desde 1964 até 1985 . Estes limites justificam-se pelo fato de que, de uma parte, a questão indígena no Brasil é um perfeito exemplo do etnocentrismo como horizonte para a construção de uma entidade que se pretende hegemônica. Exercício que leva à necessária dominação da alteridade, através de sua negação, normalização e assimilação ao Nós.

Como aponta a professora Alcida Rita Ramos $(1991,1998)$, que teve a gentileza de me convidar a dar a palestra que deu origem a este paper, o Brasil mantém, além do baixo peso demográfico, uma relação de dependência simbólico-referencial com os povos indígenas. Os textos referenciados da veterana 
antropóloga, afirmam a relação de "inimigo íntimo" que os países latino-americanos têm tido com os povos indígenas. No caso brasileiro, o índio tem estado presente sempre na construção desse imaginário tropical, de onde tem nascido todos os conceitos-chave que estruturam o que hoje é chamado de "brasilidade". Por isso, o índio como o Brasil, é imaginado como uma "res nullius" com potencial infinito, gentil e afável, mas que tem de ser domesticado, pois tem a semente, no seu interior, da grande limitação de falta de civilização e desenvolvimento, que também falta no país.

Por outro lado, o marco cronológico escolhido, a ditadura militar brasileira, é um rico cenário que dá vida a essa hipótese, já que, nele, se continuou representando o índio segundo cânones antigos, atualizados às conjunturas econômicas, sociais e políticas turbulentas daquelas décadas; e seu enfrentamento ao despertar de um movimento pró-indígena que procurava dar espaço à Alteridade tradicionalmente excluída. A ditadura de 1964 se revela como uma boa oportunidade, pela vizinhança com os tempos atuais e por ser uma época de grandes mudanças e enfrentamentos, para procurar os mecanismos etnocêntricos que levam do imaginar a o Outro a querer dominá-lo mediante sua assimilação ou destruição. O marco cronológico também será ampliado em detalhes durante o transcurso do texto ${ }^{4}$.

O interesse na questão apresentada tem sido tratado através do estudo da documentação daquele momento histórico, principalmente daquele material com potencial para criar e replicar imaginário. Por isso se destaca o estudo da imprensa, principalmente O Estado de São Paulo, O Globo, Veja e outros; os discursos de políticos registrados nos diários da Câmara dos Deputados, os testemunhos de ativistas, acadêmicos e indígenas em diferentes meios (desde a Comissão Nacional da Verdade de 2014, até documentos gerados pelas próprias instituições indigenistas, sem esquecer publicações independentes como Porantim do Conselho Indigenista Missionário). As referências detalhadas podem ser achadas no final do texto, sendo, todos elas, formatos que oferecem informação vital sobre a questão proposta, e que nos permite radiografia de um índio imaginado numa época que deu vida ao Brasil de hoje.

\section{2. $O$ fundo de fantasia que dá vida à imaginação}

Nesta ponderação, pretende-se apresentar os diferentes componentes que davam corpo ao índio imaginado pelo poder durante a ditadura militar e, neste 
sentido, o conceito de poder limita-se única e exclusivamente àqueles atores com uma forte capacidade de influenciar na realidade indígena. Tais atores podem ser o governo controlado pelos militares, suas instituições e regulamentação, assim como aqueles setores da população com interesses em imaginar o índio desumanizado, principalmente os habitantes da ruralidade, assim como certos políticos e empresários. Tem-se escolhido esta parte, para mostrar que existia uma necessidade de gerar um discurso sobre um índio alheio a nossa humanidade, para legitimar atos de violência cultural ou física, com o afã de impor os interesses dos ditos atores. Demostrando assim que, o etnocentrismo e seu filho, o Outro, não só servem para fixar uma realidade mediante sua classificação entre opostos, como também para desenhar as relações de poder e impor interesses dentro de uma lógica que legitima a dominação.

Nesta primeira seção, interessa-nos estabelecer as origens do índio como Outro. Os europeus, durante sua conformação no seu imaginário, tiveram que confrontar os grandes vazios de conhecimento que envolviam aqueles povos habitantes de uma América ainda desconhecida, cobrindo esses vazios com suas próprias referências epistemológicas. Ainda que seja um tema para falar muito (pode-se consultar meu ensaio em Trinidad, 2015, onde faço uma análise desta questão), podemos concluir que aquela solução epistemológica autorreferencial se baseava generosamente nas referências fantásticas encaminhadas pelas lendas que habitavam as bordas brumosas dos mapas, nas velhas idealizações de tempos antigos e nos textos religiosos.

\subsection{O sertão e a mata para o bárbaro e o selvagem}

Num primeiro momento, os habitantes de América foram classificados pelos exploradores europeus, dentro das estreitas margens do conhecimento que possuíam. Foi uma tarefa disparatada, baseada numa profunda e ingênua tentativa de explicar porque aquelas populações existiam fora de todo o conhecido. Tanto foi assim, que América mais que conhecida/descoberta foi imaginada (O'Gorman, 1995) como terra de promissão, generoso lugar que abraçava aos europeus que fugiam de um sistema desigual e opressor. Ao mesmo tempo, o recentemente conhecido continente continha os perigos do exotismo, do além da civilização e da religião na mais pura e dura fronteira jamais imaginada. Durante o processo de incorporação ao circuito epistemológico europeu, os habitantes daquelas terras acabaram por compartilhar as mesmas caraterísticas. 
Infelizmente, vamos ter que obviar a parte da América e seus habitantes como Paraíso Terrenal que deu origem a uma visão estereotipada concreta, que perdurou no tempo até hoje ${ }^{5}$. Por outro lado, pelo formato limitante do paper, vamos nos centrar na parte "negativa" que desenha um índio não humano. Vale lembrar ao leitor que a composição polissêmica do índio imaginado é bem mais complexa do que o retratado neste trabalho. Dito isto, podemos nos centrar em dois epítetos interessantes pela sua resistência e capacidade para sobreviver, o índio como bárbaro e selvagem.

O Brasil é um país particular, pois vive uma idiossincrasia provavelmente única no mundo, que é a de ser um país virado para o litoral. A pobreza demográfica dos portugueses e seus instintos marinheiros levaram a criar grandes urbes que jamais ficaram longe do litoral, ao mesmo tempo em que olhavam o interior como uma terra rica e de oportunidade, mas também cheia de grandes perigos ${ }^{6}$.

Essa fronteira interna se manteve no tempo, sendo uma característica sociocultural brasileira que arrastra até hoje. Para a mentalidade da sociedade hegemônica, aqueles territórios afastados supunham um cenário de espaços desconhecidos, vazios metafisicamente de civilização e ordem, isolados, inacessíveis, também perigosos, dominados pela natureza em seu estado mais bruto e puro (Amado, 1995). E, como falamos antes, seus habitantes carregavam aquelas mesmas características de bárbaros e selvagens.

A importância de conhecer isso radica-se no fato de que todos os espaços afastados das cidades (que inclusive hoje se concentram, em sua maioria, no litoral) têm sido vistos pela sociedade brasileira como espaços que oferecem oportunidades, mas, ao mesmo tempo, são perigosos e prenhes de uma alteridade hostil e sempre foram vistos como cenário de fundo na representação da história do Brasil. Assim, essas roupagens antigas do índio perduraram no tempo, dando um transfundo histórico às justificações que davam pé às políticas indigenistas, de terras e de obras públicas.

Daí a união do índio com o bárbaro, visto na tradição ocidental como o habitante incivilizado da fronteira, um ser agressivo e perigoso que apenas podia falar e criar cultura, cuja mentalidade infantil só servia para a escravidão ou a civilização por imitação (Pagden, 1988). Podia-se justificar sua exploração ou inclusive sua desaparição, como assinala o texto que pretende condenar as atitudes de certos políticos e empresários interesseiros no jornal O Estado de São Paulo: “[...] os interessados no desaparecimento do índio criticam seus hábitos 
e costumes, chamando-o de bárbaro e atrasado" (24 de fevereiro 1976).

Neste sentido, o bárbaro compartilhava caminho com o selvagem, pois, ainda que com naturezas sutilmente diferentes, compartilhavam um mesmo signo. Enquanto o bárbaro era imaginado como hordas de alteridade, habitantes de uma fronteira externa que diferenciava o "nós" do "eles", o selvagem era o habitante de uma fronteira interna que se diferenciava entre o urbano e o agreste, entre o domesticado e o caótico, e que, como o bárbaro, estava presente na mentalidade europeia/ocidental muito antes da chegada à América (Bartra, 2011). Nas lutas pelos espaços de controle e quotas de poder, manifestava-se, cruamente, o índio imaginado nos limites do humano:

"A incorporação do índio à civilização depara-nos um problema de educação e por isso, uma questão de moral e de religião. Os primitivos têm uma mentalidade infantil, não os alcançam in totum as leis dos civilizados. Para integrá-los à civilização é necessário educá-los e instruí-los. A Igreja, em virtude do mandato que recebem do seu divino Fundador, considera um dever arrebanhá-los para o Evangelho. É por isto que se encontram missionários nas brenhas onde impera o selvagem”. (Câmara dos Deputados, 28 de maio 1946, p. 2133)

"Com o parco auxilio de quatro milhões de cruzeiros da SPVEA, a expedição na qual tomou parte veio revelar ao mundo cenas da vida de uma população selvagem que continua no mesmo estágio de antes do descobrimento do País. É incrível que, num país em desenvolvimento como o Brasil, onde todas as eras da civilização se recapitulam no presente, ainda existam populações nesse estágio de selvageria”. (Câmara dos Deputados, 23 de março 1962, p. 194-195)

Como veremos depois, o reviver e não deixar morrer, ainda que seja em suas linhas simbólicas mais sutis, eram representações que terminavam por justificar políticas e violências contra os povos indígenas, por sua naturalização selvagem e, por isso, um obstáculo ao progresso, ou como bárbaro civilizável , que, com uma mentalidade infantil própria das populações inferiores a nós, devem ser redimidos por nossa benevolência superior.

\subsection{A antropofagia e a bestialização}

Seguindo a ordem de exposição, não podemos deixar passar a bestialização do índio. Um dos recursos dialéticos e gráficos mais usados era o de representar o índio como um animal sem raciocínio nem proveito, a quem era muito mais 
fácil matar do que tentar dialogar. Um elemento importantíssimo no Brasil, que ilustra perfeitamente esta linha de pensamento é a surpreendente sobrevivência da imagem do índio como antropófago, representante do medo primigênio do homem de ser devorado física e metafisicamente pela alteridade.

A antropofagia tem sido tradicionalmente um dos pilares básicos da demonização do Outro no Brasil. O canibalismo contribuía para a conformação inumana do estranho, da alteridade. Servia para tirar dele sua humanidade, já que um homem que devora outro homem não podia ser completamente humano, assim passava a ser percebido com uma máscara de bestialidade que dava corpo a sua inumanidade e, por isso, seguia vigente ainda durante a época da ditadura. Tal imagem era usada com ligeireza por políticos e servidores. Tal é o caso do deputado por Rondônia, Armando Leite, que com um discurso alarmista e até caricaturesco, começava falando dos indígenas Cintas-Larga: "Recentemente, cerca de 50 desses índios, bárbaros - e, no dizer de muitos, até antropófagos - invadiram residência desse funcionário e fizeram-no prisioneiro, juntamente com sua esposa", para terminar, dizendo: "Dizem que são grandes apreciadores de carne humana e comem-na assada com mel de abelhas” (Câmara dos Deputados, 11 de março de 1965, p. 681).

O antropófago continuava salpicando com sangue humano os dentes do índio imaginado. Grande é a capacidade de simples rumores terminarem sendo uma realidade na imprensa nacional, como foi o caso dos Nereyó/Nereyara (de quem nunca se confirmou a existência), que foram descritos pelos indígenas Tirios como poderosos inimigos, o que parece uma estratégia de afastar deles ou de certos lugares o homem branco:

"A Funai encara a possibilidade de encontrar pela frente, na área da Perimetral Norte e próximo ao Parque Nacional do Tumucumaque, ferozes índios caibais conhecidos por nereyó ou nereyana -ou ainda morcegos- sobre os quais pouco se sabe. Há apenas referências que deles fazem os índios tirios que os temem”. (Jornal do Brasil, 23 de março 1973)

Certo, além da dificuldade de comprovar dita natureza, era elemento comum nos próprios boletins internos da Fundação Nacional do Índio (FUNAI), que podia qualificar grupos indígenas como antropófagos para calibrar a dificuldade de um contato e da pacificação, assim como para louvar a bravura e valentia dos sertanistas e servidores do organismo indigenista (quando, na maioria das vezes, o 
ser ou não antropófago dependia de rumores, histórias e relatos de habitantes da fronteira ou de outros grupos indígenas). O então presidente da FUNAI, Gerônimo Bandeira de Melo, durante a construção da Perimetral Norte em 1973, chegou a pedir aos trabalhadores que construíam a estrada para ficarem especialmente atentos e nunca se afastar do grupo, já que havia presença “documentada" de índios antropófagos na zona (O Estado de São Paulo, 14 de agosto 1973).

\subsection{O processo de desumanização}

Nesta parte da exposição, pretende-se demonstrar como certas representações, baseadas em tentar dar espaço no nosso universo autorreferencial à alteridade, acabam por servir aos interesses de imposição projetados sobre essa mesma alteridade. Por isso, nas relações de poder joga-se um papel fundamental, sua representação. Neste caso, em concreto, se criava um transfundo que justificava as dinâmicas de exploração e extermínio ao ser visto o índio como um ser sem humanidade.

Está dinâmica era comum aos habitantes da fronteira interior do Brasil na época, como mostram os trabalhos do famoso sociólogo José de Souza Martins (1997) durante a década de 1960, no interior brasileiro. Em suas conversas com o que ele chama de "civilizados" (com aspas do autor), identifica no discurso (com gente de Goiás, Tocantins, Mato Grosso, Pará, Maranhão, Rondônia, Acre, Amazonas, etc.) esta dualidade do humano ou não humano, escondido com eufemismos mais ou menos sutis: 'com aqueles pode falar porque são cristãos e com aqueles não, porque são índios', 'este lugar é frequentado por homens e às vezes, por caboclos', etc. Esta dualidade de pertencimento ou não à humanidade, a nós ou a eles, sempre segundo Souza Martins, é um eixo transversal que cruza o tempo desde os primeiros compassos do Brasil colonial até hoje, "em que essas categorias demarcavam com mortal severidade, como ainda hoje, de certo modo, os limites étnicos dos pertencentes e dos não pertencentes ao gênero humano" (Martins, 1997:28).

Sob estas mesmas premissas, podem-se resgatar muitos depoimentos, como aquele do antropólogo Herbert Baldus quando interrogava, ao final de 1959, um velho caboclo sobre índios trucidados "Matamos tudo, porque o índio é pior que bicho, pois tem as unhas venenosas" (Stauffer, 1959:87). Ou o bispo espanhol Pedro Casaldáliga (1971) que, quando no começo da década de 1970, tomando pose de sua diocese em Mato Grosso (São Felix do Araguaia), escreveu horro- 
rizado que o índio não era considerado "gente" pelos sertanejos e camponeses. Seguindo com exemplos, pode-se falar dos Cintas-Larga no tristemente famoso massacre do Paralelo-11, no qual uma expedição criada especificamente para abater aquela comunidade acabou por chegar ao conhecimento público, mostrando a crueldade do ato. Num discurso, o deputado Arruda Câmara resgata o depoimento de um dos assassinos, no qual descreve a morte de crianças com tiros na cabeça ou como uma mulher é pendurada numa árvore e cortada pela metade, porque "um índio vale menos que um cachorro" (Câmara dos Deputados, 11 de junho 1968, p. 3361). Ou ainda o uso de indígenas escravos, seja como prostitutas ou como escudos humanos (como aconteceu com os indígenas Suruí e Aikewara) pela Força Armada Brasileira (FAB) na sua luta contra a Guerrilha do Araguaia. Outro caso interessante foi quando um indígena da Guarda Rural Indígena (GRIN) foi disciplinado por prender um branco: "Índio não pode prender branco" (Veja, 15 de abril 1970), lembrando-lhe sempre que a autoridade emanava do branco para o índio, ou seja, o índio era subalterno da comunidade nacional dominante. Havia a "coisificação" do índio, que deixava o plano humano para ser visto como paisagem nas conversas informais entre servidores da FUNAI, à hora de classificá-los segundo o recurso cobiçado na sua terra. Assim, chamavam “cassiteritas” aos indígenas que senhoreassem um território rico nesse cobiçado mineral (sinalando o fatal destino que lhes esperava), ou "bois", se suas terras tinham sido designadas para ser exploradas pelo negócio agropecuário (Veja, 25 de maio 1971).

“Morriam de dez a vinte índios por dia”, relatava Tiuré (José Humberto do Nascimento), funcionário da FUNAI que resolveu se exilar no Canadá, mostrando a realidade dos Parkatêjé sob a tutela dos militares da FUNAI. A realidade desta tribo do Pará, localizada no município de Bom Jesus do Tocantins, é expositiva da terrível realidade vivenciada por muitos dos povos indígenas sob a tutela da FUNAI e das instituições oficiais. O escrito de Liliam Milena (2012) segue o rastro deste mesmo grupo indígena, que desde 1966 vivia em regime de escravidão sob a autoridade da FUNAI, com o monopólio do comércio da castanha-do-pará que os indígenas recolhiam, numa lógica de dívida eterna. A morte dos Parkatêjé era constante e agônica, em pouco mais de uma década passaram de mais ou menos duas mil e duzentas pessoas. O fato de seu território ancestral ficar sobre um dos maiores depósitos de ferro do mundo à época pode esclarecer um pouco o porquê. Hoje, nesse território, tem sede o projeto 
mineiro Grande Carajás. Disponível em: <https://blogdotiure.wordpress. com/>. Acesso em: 5 de jan. 2014.

Esta desumanização perseguia, inclusive, populações como a cabocla, considerada meio indígena. Para a sociedade hegemônica, o índio se mantinha sob a pele do habitante amazônico. A alteridade estigmatizada perdurava no caboclo, deste modo, ia além do desaparecimento físico e cultural do índio.

[...] O branco 'classe alta' fundamenta sua objetivação do caboclo no prejuízo que este lhe acarreta no cumprimento das atividades de produção; o branco 'classe baixa', baseado nas mesmas evidências de baixa produtividade, estigmatiza o caboclo com termos similares, todos expressando a diferença essencial existente entre seringueiros de etnia diversa: 'O caboclo trabalha mal porque ele é mais pra bicho do que pra gente'. E muitos alardeiam que seu trabalho vale o de dez caboclos. (Oliveira, 1995:146)

As correrias (expedições punitivas e de apresamento) na Amazônia e os caçadores profissionais de bugres tinham sobrevivido bem até o século XX, quando o indigenismo oficial conseguiu acabar com a maioria destas atividades. Mas a conivência por omissão também formou parte desse enfrentamento com a alteridade, como demonstra a tese doutoral da antropóloga Carmen Lucia da Silva (1998). Em seu trabalho, narra a triste história dos Xetá de Paraná, que durante a década de 1960 foram exterminados pelo avanço implacável da colonização, o desmatamento e a exploração da terra. Durante este processo, morreram assassinados, por penúria, doenças, envenenamentos, sequestros e incêndios de suas terras e aldeias, sobrevivendo apenas um pequeno grupo de pessoas que serviram à pesquisadora como informantes.

Pode-se interpretar estes sucessivos massacres e extermínios por que os indígenas, as pessoas físicas, passam pelo filtro da alteridade no limite do humano, ou seja, vistos como índios bárbaros, selvagens e incômodos? Se toda a sociedade do Paraná, neste último caso revelado por Silva, era conivente (conhecedora, participante e encobridora), e por extensão, a sociedade brasileira, será que existiam construções mentais que permitiam ver como "natural" a extinção de povos inteiros?

\section{Os centros reguladores da imaginação}

Como temos visto até agora, a construção de um imaginário concreto ao 
redor do índio, levou-o a viver sempre nos limites de uma humanidade questionada. Como já comentado, esta situação é comum a toda alteridade vista desde o etnocentrismo, no caso dos povos indígenas, sua inclusão nas fronteiras periféricas de um etnocentrismo com tendência à imperialidade, como a sociedade colonial/nacional brasileira levou-lhes a viver uma situação de conflito inter-étnico perpétuo e assolador.

Nesta segunda parte, vamos tentar conectar aquelas roupagens antigas de lembranças fantásticas que adornavam o índio com a forma com que eram tratados os povos indígenas durante a ditadura militar, com a intencionalidade de reflexionar como toda dominação passa primeiro por imaginar o outro como um ser que precisa ser dominado.

\subsection{O índio como empecilho ao progresso da nação}

Anteriormente, vimos como o índio adotava necessariamente os adjetivos do território no qual vivia, o mato ou o sertão. Estes territórios, como eram o sertão (na sua dimensão como fronteira afastada dos centros civilizados e não a região nordestina), a selva e os vastos interiores, tinham como seus habitantes naturais os índios selvagens e bárbaros, os mesmos que se opunham ao avanço do processo normalizador e civilizador que Brasil desejava.

Por isso, os índios eram considerados um obstáculo ao desenvolvimento, vistos pela maioria dos habitantes da fronteira como parte de uma paisagem que tem que ser domesticada. Por um lado, o índio era visto como uma parte incômoda da natureza que impedia o correto funcionamento das lavouras, assim como podia ser uma onça ou um jacaré. Por outro lado, a existência ou chegada de índios podia atrair atenção demais, trazendo molestos inspetores do Serviço de Proteção do Índio (SPI) / Fundação Nacional do Índio (FUNAI), imprensa ou ativistas e missionários.

A esta situação se somava a fraqueza das estruturas do Estado naquelas fronteiras interiores, o relaxamento das normas sociais e morais "normais" no resto do país, a necessidade de criar estratégias de sobrevivência e convivência, a falta de infraestruturas, etc. Esta situação outorgava à fronteira um perigo contínuo diante de uma natureza esmagadora, incômoda e poderosa, na qual parece só se sentir cômodo aquele índio estranho que mostrava de forma impertinente o se pertencimento essencial àquele lugar. E é por essa razão que virava o outro no espelho, sobre o qual construir um "nós". 
Claro, a violência era parte do discurso que clamava pela bestialidade do índio naturalizado. Por exemplo, em agosto de 1980 houve um massacre de peões contratados por fazendeiros locais, assassinados por indígenas do norte do Parque do Xingu, que diziam defender suas terras. Durante as conversas iradas entre os diferentes representantes e fazendeiros, estes últimos, exaltados, evidenciavam essa dimensão: "[...] eu concordo que o índio tem direito à vida, mas é preciso se compreender que ele é um animal, precisa ser educado”, assinalava Luiz Carlos, fazendeiro local, assim como Moacir Prata Pereira, da mesma condição e ainda mais enraivado enquanto gritava aos missionários do CIMI (que registravam a conversa) que anotassem suas palavras: "[...] índio é igual a cachorro. Eles todos são andarilhos, ladrões preguiçosos, assaltantes. Minhas galinhas têm melhores condições do que eles. [...] Se algum índio parecer na minha terra, eu mato sem pensar" (Porantim, setembro 1980).

O discurso do índio naturalizado era especialmente visível entre a elite e a população da fronteira que o viam como oficialmente protegido pelo Estado, e que o supunham como um empecilho às necessidades urgentes de desenvolvimento daquelas zonas deprimidas economicamente, diferentemente da sociedade urbana brasileira, que via o índio através do caleidoscópio romântico e folclórico do pensamento social, a sociedade rural. Colonos, boias-frias até fazendeiros e políticos, tinham uma visão muito mais visceral e passional sobre o tema, evidenciado nos discursos de Jorge Teixeira de Oliveira, prefeito de Manaus (Porantim, 1979) que os chamava "bobalhões parasitas"; ou Luís Paes Leme de Sá, secretário de governo do território de Rondônia (O Globo, 1 de julho 1973) "não pode parar [o desenvolvimento] só para resguardar uma raça já em extinção”; ou do fazendeiro de Barra das Garças Geraldo Figueiredo (O Globo, 14 de setembro de 1973) "esses índios estão entravando o desenvolvimento nacional”. Ao mesmo tempo, o General Federico Rondon (O Estado de São Paulo, 26 de abril 1972) propunha pôr a produzir os indígenas de forma efetiva. Ou como declarava o governador de Roraima, Fernando Ramos Pereira (O Estado de São Paulo, 1 de março 1975), que "não se pode dar o luxo [Roraima] de conservar meia dúzia de tribos indígenas atravancando o desenvolvimento".

Este último caso, aquele de Roraima, é especialmente significativo, pois o interesse em fazer do lugar uma região competitiva levou a criar políticas de ocultação do índio e vetar sua presença em qualquer tipo de meio que pudesse 
chamar a atenção sobre as populações que, para os políticos, fazendeiros e empresários locais, não existiam:

“Tanto na imprensa de Roraima, o quinzenal "Jornal da Boa Vista" e "O Roraima”, de periodicidade irregular, como na TV e nas rádios controladas pelo governo, é proibido falar sobre índios. A diocese católica, que tem um espaço nesses meios de comunicação, foi obrigada a aceitar esta imposição se quisesse prosseguir com suas programações. Esta proibição é fruto de uma mentalidade difundida na sociedade envolvente roraimense segundo a qual o índio é um empecilho ao desenvolvimento deste território que, seguindo o exemplo de Rondônia, almeja tornar-se Estado”. (Aconteceu Especial, 1982, p. 86)

\section{2. $O$ índio como perigo à ordem nacional}

As regiões habitadas pelos povos indígenas eram imaginadas pela ditadura como vazios estratégicos que supunham um déficit interno de desenvolvimento e, por isso, de segurança. Um horror vacui intenso e sufocante que via o vazio de civilização como um abismo existencial por onde se podia sumir no seio da selvageria e da barbárie, um inimigo invisível que pretendia a degradação moral, espiritual e cultural contínua contra os pioneiros que tentavam desbravá-la.

Não se pode esquecer que a segurança era o eixo central que sustentava a legitimidade do regime de "democracia autoritária", imposta pelos militares com a conivência das elites econômicas em 1964. Os generais brasileiros entendiam o mundo, em geral, e o Brasil em particular, como um conflito ideológico que introduzia o país numa guerra cotidiana. Nestes lugares, o índio, representante selvagem/bárbaro de uma natureza sem domesticar/aproveitar, passou a formar parte dos grupos populacionais que potencialmente podiam apoiar seus antagonistas ideológicos.

O governo achou a legitimidade e o apoio necessário para poder interferir agressivamente nas comunidades e pacificar rapidamente os grupos de índios arredios. Se uma população indígena mostrava especial bravura ou resistência, eram suspeitos de obter ou dar apoio a guerrilhas comunistas. Um bom exemplo disso, é o que mostra o general Altinio Berthier, participante do conflito com os Waimiri-Atroari na década de setenta, numa entrevista: "Aqueles índios eram muito aguerridos. Até diziam que andavam insuflados por cubanos, estrangeiros". (Ochoa, 2001) ${ }^{7}$.

O halo de suspeita que voava continuamente sobre os povos indígenas, e 
quem os apoiava, foi constante no tempo. Em documentos do Conselho de Segurança Nacional pode-se comprovar como eram investigados desde grupos estudantis e sindicais que falavam da questão indígena, até ONGs (nacionais ou internacionais) e missionários (especialmente do CIMI); vistos como perigosos por ter estrangeiros demais e estar sempre presentes nas aldeias. As influências estrangeiras eram fonte de insegurança, criavam possíveis focos de subversão, que desestabilizavam as regiões habitadas pelos povos indígenas (CNV, 2014:205). O próprio CIMI era habitualmente investigado como um foco de comunismo de especial perigo, mas também eram considerados como tais e, portanto, vigiados pesquisadores e periodistas, inclusive servidores da FUNAI que apoiaram abertamente o livre direito de reunião das lideranças indígenas.

Nesta linha enquadra-se o forte debate e demarcação, a portas fechadas, do Parque Ianomâmi. Os técnicos pensaram que um Parque indígena tão grande como o estado do Piauí poderia virar um Estado independente, comprometendo a segurança nacional. Sobretudo ao ser fronteira com Venezuela, cada vez maior na luta indígena e sua vontade de se chamar "nações indígenas" (O Globo, 09 de abril 1981).

Tantos outros eventos continuam nesta linha. Por exemplo, a questão da emancipação proposta pelo ministro do Interior Rangel Reis, em 1978, e continuada pelo presidente da FUNAI, Nobre da Veiga, em 1981. Nesta iniciativa que pretendia fechar a questão indígena definitivamente, podem-se achar características comuns ao conflito, assim como à ideologia dominante no Estado e na elite brasileira. $\mathrm{O}$ medo que havia nas terras indígenas nas fatias fronteiriças com outros países ou as pressões para que toda discussão sobre terras indígenas passasse por um Conselho Nacional de Segurança, criaram a imagem do índio como ameaça à segurança nacional, que dificilmente conseguia esconder certos interesses e pressões dos diferentes grupos econômicos e de poder, e sua projeção sobre as terras indígenas ${ }^{8}$.

Esta situação fez do índio um dos objetivos principais de controle, por medo a sua subversão espontânea ou por influência de ideologias e forças revolucionárias que operavam na América Latina naquela época. Um direto expoente desta situação foi a criação do GRIN, em 1969, e da prisão especial do Crenaque, que mostram mecanismos de repressão especiais contra os povos indígenas (FUNAI, Boletim Museu do Índio, etnohistoria n.1, maio/1979). No IITribunal Russel em 1974, que investigava e julgava crimes contra os direitos humanos, houve denúncias sobre a existência desta prisão. Como exemplo, resgatamos 
um depoimento da Comissão Nacional da Verdade, especialmente ilustrativo:

Com relação aos índios, o clima é de terror. Contrariando seus Estatutos e atentando contra os direitos humanos, a Funai criou uma prisão para os índios em Crenaque, no município de Governador Valadares, Minas Gerais. Na gestão de Bandeira de Melo a prisão tem sido muito usada. Segundo palavras do sertanista Antônio Cotrim Soares, jamais contestadas pela Funai, Crenaque "é um campo de concentração" para onde são enviados os índios revoltados com o sistema explorador e opressivo da Funai. A prisão é dirigida por um oficial da PM de Minas Gerais, comandando um destacamento de seis soldados. Os índios presos são obrigados a um regime de trabalho forçado de oito horas diárias. São colocados em prisões celulares, isolados uns dos outros. E recebem espancamentos e torturas. Cotrim conta o caso do índio Oscar Guarani, de Mato Grosso, que ao entrar na prisão pesava 90 quilos e de lá saiu pesando 60, além de apresentar marcas de sevícias no corpo. (CNV, 2014:238)

Esta iniciativa do Estado (sob a supervisão da FUNAI) revela que a complexidade da fronteira se projetou sobre a complexidade do próprio tempo histórico no qual se desenvolvia a ditadura militar, multiplicando essa mesma complexidade. Isso levou ao fato de fora quase impossível achar soluções à questão indígena. A contradição era absoluta, precisava-se achar remédios que não acelerassem os processos de desaparição cultural e física dos povos indígenas na sua integração inexorável à sociedade nacional (na teoria, o trabalho da FUNAI, vigiado constantemente pela opinião pública). Mas, ao mesmo tempo, essa solução devia responder aos rápidos ritmos impostos pelo voraz apetite da economia global, que os generais brasileiros gostavam de mimar. Por isso, para os militares que comandavam o órgão indigenista parecia impossível adiantar o processo de "integração/assimilação, na medida em que o índio estivesse sob controle e harmonizado com os padres da ordem (ou desordem) estabelecida" (CNV, 2014). O encarregado da GRIN, Capitão Pinheiro, numas declarações ao Jornal do Brasil, em 27 de agosto de 1972, mostra a necessidade de controlar o índio para poder continuar as linhas da Doutrina de Segurança Nacional: O índio é fator de segurança nacional, pois, quando ele se revolta, cria desordem e subversão e, deste modo, depois de preso pela GRIN, é enviado a Crenaque (colônia penal indígena) para reeducar-se e ser um índio bom. 


\subsection{O índio imaginado pelas políticas indigenistas}

Como tem sido reconhecido nas páginas anteriores, a FUNAI, como órgão indigenista, vivia numa conivência com o poder (com honrosas exceções) e seus interesses nas terras indígenas, mas... Compartilhava a mesma forma de representar o índio?

O indigenismo contemporâneo, que nasceu da vontade positivista do círculo político-militar de Rondon e que continuou a FUNAI até a constituição de 1988, fundamentou-se, então, num parâmetro de conquista que forçava o contato usando a "pacificação" (Lima, 1992). Esta era uma espécie de combate/ batalha simbólica onde a superioridade tecnológica, civilizatória e moral submetia por assombro às populações nativas. Segundo esta linha de pensamento, os indígenas terminavam por compreender sua inferioridade através dos presentes que lhes eram outorgados e pela atitude altiva de integridade militar/ espiritual constitutiva dos civilizados. Aí, o índio admitia que o único caminho possível era abraçar o progresso ocidental que o levaria a se integrar nos ritmos contemporâneos ao amparo de uma nação moderna. Depois da "batalha" da "pacificação" (cuja metodologia demora meses, com o "namoro" ou intercâmbio de presentes), se impunha o processo pedagógico-militar. A Modernidade que, segundo sua própria mitologia, tinha que compartilhar sua superioridade cultural e moral com as populações bárbaras e selvagens, se impunha de novo atualizada às conjunturas pelas quais o Brasil passava por aquele tempo.

Por isso, acabou por se unir a necessidade de integrar num só individuo toda a nação (para consumar a democracia racial e o homem tropical) e controlar aquelas populações rebeldes, alheias e estranhas ao "pato social”, a alteridade para a qual a nação tem sido desenhada. Havia a necessidade de "ocupar" com desenvolvimento os territórios vazios, a expansão econômica e o triunfo do projeto da Modernidade, se impondo como os únicos projetos naturalmente viáveis. Numa viagem onde a alteridade é vista como um potencial "nós", adaptados e sobrevivendo ao processo, poderiam compartilhar a mesma natureza humana.

Isso levou as instituições e a legislação indigenista ao mesmo ponto resenhado até agora, o imaginar o índio como um inferior a educar, terminando por naturalizar sua exploração e massacre. Neste sentido, e como relata o informe da CNV de 2014, no indigenismo, entre 1946 e 1988, houve uma linha de ação por parte do Estado com sua política indigenista, caracterizada por duas épocas diferenciadas, mas consequentes, fruto desse longo processo histórico. O primeiro período 
seria o protagonizado pelo SPI (1946-1967), que iria até sua desaparição, no qual o Estado estabeleceu condições propícias para os saqueios das terras indígenas, principalmente por omissão. Cobriram-se as ações do "poder local, interesses privados e deixando de fiscalizar a corrupção em seus quadros” (p. 198).

Foram emitidas amiúde declarações oficiais fraudulentas que atestavam a inexistência de índios nas áreas cobiçadas por particulares. Para tomar posse dessas áreas e tornar real essa extinção de índios no papel, empresas e particulares moveram tentativas de extinção física de povos indígenas inteiros - o que configura um genocídio terceirizado - que chegaram a se valer de oferta de alimentos envenenados, contágios propositais, sequestros de crianças, assim como de massacres com armas de fogo. Em 1967, o Relatório Figueiredo, encomendado pelo Ministério do Interior, de mais de 7.000 páginas e 30 volumes, redescoberto em novembro de 2012, denuncia a introdução deliberada de varíola, gripe, tuberculose e sarampo entre os índios. (CNV, 2014:201)

O segundo período vai desde o nascimento da FUNAI e o endurecimento da ditadura, especialmente com a assinatura do AI-5 em 1968. Nessa época, o próprio Estado tomou parte ativa no processo etnocida, não só aprofundando a omissão em saúde ou controle de corrupção, também no favorecimento dos grandes interesses privados, sempre afetando negativamente os direitos dos povos indígenas.

Encontram-se paralelismos claros entre as duas instituições indigenistas. Visíveis no próprio Relatório Figueiredo, depoimentos de servidores do SPI mostram um claro esquema de saqueio protagonizado pelo Ministério de Agricultura (que naquele momento controlava o SPI) e que envolvia políticos regionais e locais, atores econômicos das zonas interessadas, agentes do SPI e do ministério. Segundo Helio Jorge Bucker, sertanista:

[...] dos esbulhos de terras indígenas de que tenho conhecimento (...), nenhum foi mais estranho e chocante do que o procedido diretamente pelo Ministério da Agricultura, através do seu Departamento de Terras e Colonização. (...) O próprio órgão responsável pela garantia da terra do índio, é o primeiro a despojá-lo. Penso que fica bem claro com esse exemplo que a espoliação tem a chancela oficial das cúpulas administrativas, maiores responsáveis pelas desditas dos índios e do Serviço de Proteção aos Índios, o bufão da grande comédia [...]. (Relatório Figueiredo, p. 3.952-3.953 apud. CNV, 2014:202) 
Ao nascer, a FUNAI começou a funcionar como parte do Ministério do Interior, como um elemento mais de maquinaria colonizadora que avançava pelas matas virgens e que era a causante do desaparecimento indígena: "a Funai vincula-se ao ministério "dinâmico" responsável pelos grandes projetos de desenvolvimento econômico-financeiro-regional” (CNV, 2014:202).

Esta lógica não era alheia à legislação, onde se impunha o racismo como a lógica que dominava as entranhas do sistema. Como hoje sabemos, o poder do racismo não fica na evidente dominação entre centros e periferias, onde se localizam as populações que vivem sob as lógicas conjunturais do colonialismo tradicional. Essa visão simplificada do racismo, comum naquela época, era rejeitada oficialmente pelo Brasil como ex-colônia europeia. Além disso, o racismo não era considerado nas análises que tentavam entender as dinâmicas do país, como, por exemplo, na explicação da desigualdade, que era só vista sob dinâmicas econômicas ou na luta de classes.

O verdadeiro poder do racismo está em gerar e reproduzir lógicas de dominação e poder baseadas na razão colonial, ou seja, na superioridade racial, aprofundando-se além das evidentes mostras de desprezo entre pessoas de diferentes cores de pele. As lógicas herdadas do mundo colonial, a chamada colonialidade no pensamento latino-americano (Castro Gomez, 2000), sobreviviam ao próprio colonialismo. Este pensamento defende que as lógicas de diferenciação racial feitas durante o período colonial, e que enriqueceram os países europeus, produziram uma ferida que nunca foi curada nas sociedades contemporâneas latino-americanas, e que é responsável pelos grandes problemas das mesmas (Quijano, 2007; Mignolo, 2003).

Por outro lado, temos o pensamento de Franz Fanon (exposto desde a perspectiva decolonial por Ramón Grosfoguel) que defende que o racismo era uma hierarquia global de superioridade e inferioridade sobre a linha do humano que tem sido politicamente produzida e reproduzida durante séculos pelo "sistema imperialista/ocidentalocentrico/capitalista/patriarcal/moderno/colonial” (Grosfoguel, 2011). Pensamento que reforça a reflexão deste artigo sobre a necessidade de imaginar o outro nos limites do humano.

A FUNAI foi criada sob a premissa do relacionamento desigual entre o indígena e o Estado. A instituição tratou o indígena, oficialmente, como um ser passivo e primitivo que dependia da tutela estatal não só para sobreviver, também para se desenvolver “corretamente”. Esta institucionalização do racismo 
respondia a este racismo que se aninhava na alma do Brasil. A legislação da qual nasceu a FUNAI (Lei n ${ }^{\circ}$ 5.371, 5 de dezembro 1967) constatava essa situação ao estabelecer uma dominação prática e legislativa sobre o índio, que não dava a ele o direito de negociar ou se opor.

Por isso, pode-se comprovar porque a FUNAI teve um caráter policial e arbitral entre os povos nativos. Este marco jurídico foi ratificado e ampliado na sua concepção racista e de dominação com o Estatuto do Índio de 1973, que manteve um respeito aparente à normativa internacional antirracista e de apoio aos povos indígenas, mas escondeu os mecanismos necessários para continuar com as lógicas tradicionais de imaginação/dominação.

"O índio para a FUNAI - diz o presidente - é um ser humano, filho de Deus e digno de todo respeito, estimulo e dedicação. A ele deverão ser dados todos os implementos morais, econômicos e sociais para que dentro de prazo flexível ele possa integrar-se ao mundo civilizado" (Bandeira de Mello, resgatado de O Estado de São Paulo, São Paulo, 22 de maio 1971).

Durante a gestão do ministro do Interior Mauricio Rangel Reis e Araújo de Oliveira, como presidente da FUNAI (1974 e 1978), foi gestado o já falado projeto de emancipação que pretendia liberar da tutela os povos indígenas que demonstrassem "não ser mais índios". Este foi um conceito que se consolidou no horizonte político dos dirigentes militares, sobretudo a partir da criação do mecanismo legal que estabeleceu o Estatuto do Índio de 1973, que outorgava a capacidade aos povos indígenas de se "emancipar" da tutela do Estado, quando sua integração fosse completa. Com a "liberalização" do indigenismo durante sua época militar, foi crescendo entre os dirigentes da FUNAI, ao longo da década de 1970, a ideia de que já tinha chegado a hora de que o índio deveria se desfazer do jugo tutelar e se converter em cidadão da "União". Foi uma ideia que gerou uma forte oposição em amplos setores da opinião pública nacional e internacional. Durante o ano de 1978, a luta entre o ministro e a FUNAI contra indigenistas, antropólogos, missionários e lideranças indígenas foi feroz, acabando com o projeto engavetado, com o fortalecimento do movimento indígena e pró-indígena e a confirmação definitiva do desprestígio da FUNAI que ainda hoje não recuperou totalmente. 


\section{Conclusões}

Podemos concluir que existe um paralelismo à hora de imaginar a alteridade com certas características que legitimassem umas práxis de contato que levava à eliminação/assimilação. Por um lado, é visível que, ao delinear características a partir de conceitos como bárbaro, selvagem ou canibal, não se pretendia só outorgar atributos, mas elaborar a realidade que designavam (Kiening, 2014). Criou-se um imaginário que conformava uma realidade substancial, surgida a partir da interpretação da realidade (uma espécie de mimetismo epistemológico) que se estava vivendo junto com a intenção de fixar conhecimentos já assentados (o marco referencial epistemológico). Assim, se podia continuar caminhando diante de realidades novas sem que as sociedades que se pretendiam hegemônicas padecessem da loucura da insegurança, e de se questionar as bases que legitimavam seu próprio labor de imperialidade. Esta dupla projeção levava à produção de duplicidades contínuas que contrapunham o "nós" contra a alteridade (civilização/barbárie, ordem/desordem ou história/não história), entre a própria alteridade (bom ou mal selvagem) ou também entre o "nós" contra nós mesmos (cultura/degeneração, urbanidade/naturaliza idílica). O índio era produto desse processo de construção do eu, que precisava parasitar a alteridade sacrificável.

Por outro lado, parece que imaginar assim o índio pelo poder era necessário, pois o lidar com essa alteridade ainda tangível e oposta a todos os valores nacionais (em positivo ou em negativo, como temos visto) florescia como um exercício de desbravamento do Brasil. Era a justificação da exploração da floresta e sua necessária domesticação, na que se procedia a sua exploração racional. Assim, o índio na ditadura era um giro novo, a sua projeção bestial, onde podemos perceber que a hibridação na sua estrutura é total. Era um ser polissêmico e múltiplo que se adaptava às necessidades elementares e conjunturais da narrativa nacional ao longo de sua existência. Era selva, natureza, selvageria, empecilho aos desbravadores heroicos que levavam os litorais aos sertões.

O imaginar de certa forma a realidade não só fala de como interatuamos com ela, também de como queremos que essa realidade seja. Por isso, parece que normalizar a ação de dominação do outro (através do desaparecimento e da assimilação desse outro em nossa normalidade, poupando só os aspectos de folclore necessários para reforçar a nossa identidade) nasce do exercício de imaginar essa alteridade como uma entidade não só longe do 'Nós', mas também 
como um empecilho a se eliminar, pois entrava a nossa normalidade existencial. Este artigo tem tentado apresentar uma introdução ao estudo desses mecanismos, propondo como cenário a ditadura brasileira, na qual se criaram as paisagens ideológicas e de identidade onde mora hoje o Brasil.

Recebido: 07/10/2017

Aprovado: 20/02/2018

Carlos Benítez Trinidad é historiador, mestre em Estudos Latino-americanos pela Universidad de Sevilla e doutor em História de América Latina pela Universidade Federal da Bahia e a Universidad Pablo de Olavide. Fundador e membro do Conselho Editorial da revista-rede Iberoamérica Social, tem estudado o poder simbólico dos povos indígenas durante a ditadura. Atualmente, seu principal interesse de pesquisa são as heranças coloniais no imaginário contemporâneo brasileiro. Contato: carlos.bt.86@gmail.com

\section{Notas}

1. Texto escrito para a palestra "A questão indígena sob a ditadura militar" no Seminário do Laboratório de Indigenismo e Etnologia Indigna (LINDE) da Universidade de Brasília, no 27 de abril de 2017. Aliás, é uma aproximação à pesquisa concluída na tese doutoral "Un espejo en medio a un teatro de símbolos: el indio imaginado por el poder y la sociedad brasileña durante la dictadura civil-militar (1964-1985)”, defendida na Universidade Federal da Bahia em 7 de abril de 2017. Disponível em: $<$ https://repositorio.ufba.br/ri/handle/ri/22235>. Por último, parte dos dados e exemplos documentais reproduzidos neste texto, foram publicados em outros meus trabalhos em espanhol listados nas referências ao final.

2. Agradecer à Priscila de Oliveira Silva, Laura Sampietro e a João do Amaral as correções e dicas em formais e no português.

3. A sobrevivência dessas lógicas explica em boa parte a visão euro-ocidental do que é o "nós" e o "outro", coisa visível quando sofremos e nos sensibilizamos até o extremo 
com um ataque terrorista em Paris ao mesmo tempo que um evento igual em Bagdade ou Alepo não cria a mesma sensibilidade.

4. Para ampliar conhecimentos sobre o tema, se recomenda começar pelo humilde trabalho de Heck (1996) sobre a política indigenista durante a ditadura, e o enciclopédico texto de Hemming (2003) sobre a questão indígena brasileira durante o século XX.

5. Esta projeção histórica continuou tendo seu eco no tempo na construção contemporânea e hiper-real do índio ecologista e ativista anticapitalista (Ramos, 1995).

6. Bons exemplos desta situação é que durante séculos São Paulo foi considerada a porta ao interior continental, sendo uma cidade que distava do litoral uns poucos centos de quilômetros; ou que a primeira grande e exitosa colonização do interior com grandes cidades, não aconteceu até bem entrado o século XVIII com as explorações mineiras de Minas Gerais.

7. O caso dos Waimiri-Atroari é um bom exemplo da desumanização do índio e o uso da violência em consequência. Esse povo foi aniquilado quase completamente a o longo da década de 1970 no qual passaram de ser 3000 indivíduos a 500 em três anos (Schwade, 1992). Na chamada Operação Atroaris, o Estado implantou uma imensa força militar com alvo de "proteger" aos trabalhadores e que terminaram por massacrar indígenas com bombas, metralhadoras, doenças e fome: "A festa já estava começando com muita gente reunida. Pelo meio-dia, um ronco de avião ou helicóptero se aproximou. O pessoal saiu da maloca pra ver. A criançada estava toda no pátio para ver. $\mathrm{O}$ avião derramou um pó. Todos, menos um, foram atingidos e morreram [...] Os alunos da aldeia Yawará forneceram uma relação de 33 parentes mortos neste massacre" (CNV, 2014:229).

8. O índio ligado ao interesse militar, tradicional na história do Brasil, não acabou com a ditadura, ao contrário, continuou numa linha mais dura. Para aprofundar no tema, recomendamos o livro organizado por João Pacheco de Oliveira, 1990, listado nas referências.

\section{Referências bibliográficas}

AMADO, Janaína. 1995. “Região, Sertão, Nação”. Estudos Históricos. 8 (15): 145-151.

BARTRA, Roger. 2011. El mito del salvaje. México: Fondo de Cultura Económica.

CASALDÁLIGA, Pedro. 1971. Uma Igreja da Amazônia em conflito com o latifúndio e a marginalização social. São Paulo: Impressa.

CASTRO, Eduardo Viveiros de. 2002. “O nativo relativo”. Mana. 8 (1): 113-148.

CASTRO-GÓMEZ, Santiago. 2000. “Ciencias sociales, violencia epistémica y el 
problema de la "invención del Otro". In: LANDER, Edgardo (Org.). La colonialidad del saber: eurocentrismo y ciencias sociales. Perspectivas Latinoamericana. Buenos Aires: CLACSO, p. 191-213.

GROSFOGUEL, Ramón. 2011. "La descolonización del conocimiento: diálogo crítico entre la visión decolonial de Frantz Fanon y la sociología descolonial de Boaventura de Sousa Santos". Formas-Otras: Saber, nombrar, narrar, hacer: 97-108. Barcelona.

GRUZINSKI, Sergei. O Pensamento Mestiço. 2004. São Paulo: Companhia das Letras. HECK, Egon Dionísio. 1996. “Os índios e a caserna - políticas indigenistas dos governos militares - 1964 a 1985”. Dissertação (Mestrado ciências políticas), Universidade Estadual de Campinas. Campinas.

HEMMING, John. 2003. Die IfYou Must: Brazilian Indians in the Twentieth Century. London: Pan Macmillan.

KIENING, Camilla. 2014. O sujeito selvagem: pequena poética do Novo Mundo. São Paulo: Edusp.

LIMA, Antonio Carlos de Souza. 1992. "Um grande cerco de paz: poder tutelar e indianidade no Brasil”. 335 f. Tese (Doutorado em Antropologia Social, Universidade Federal do Rio de Janeiro. Rio de Janeiro.

MALDONADO-TORRES, Nelson. 2007. "Sobre la colonialidad del ser: contribuciones al desarrollo de un concepto”. In: CASTRO-GÓMEZ, Santiago; GROSFOGUEL, Ramón (Org.). El giro decolonial. Reflexiones para una diversidad epistémica más allá del capitalismo global. Siglo del Hombre editores. pp. 127-167. Bogotá: Siglo del Hombre Editores.

MARTINS, José de Souza. 1997. Fronteira, A degradação do Outro nos confins do humano. São Paulo: Hucitec.

MIGNOLO, Walter. 2003. The darker side of the Renaissance: Literacy, territoriality, and colonization. Michigan: University of Michigan Press.

MILENA, Lilian. 26 de julho 2012. "O massacre de indígenas na Ditadura Militar. Brasiliana, org. Disponivel em: <http://advivo.com.br/materia-artigo/o-massacre-de-indigenas-na-ditadura-militar>. Acesso: 04 de jan. 2014.

O’GORMAN, Edmundo. 1995. La invención de América. México: Fondo de Cultura Económica.

OCHOA, V. 2010. "Já estamos com os bárbaros dentro de casa. Entrevista a Altino Berthier Brasil”. Revista Extra Classe, São Paulo.

OLIVEIRA, Ana Gita. 1995. O Mundo Transformado, Um Estudo da Cultura de Fronteira no Alto Rio Negro. Belém: Museu Paraense Emílio Goeldi. 
OLIVEIRA, João Pacheco de (Org.). 1990. Projeto Calha Norte, Militares, índios e fronteiras. Rio de Janeiro: Editora UFRJ.

PAGDEN, Anthony. 1988. La caída del hombre natural. El indio americano y los orígenes de la etnología comparativa. Madrid: Alianza Editorial.

QUIJANO, Aníbal. 2007. "Coloniality of Power, Eurocentrism, and Latin America”. Nepantla:Views from South, v. 1, 3, pp. 533-580. Baltimore.

RAMOS, Alcida Rita. 1991. "A hall of mirrors: The rhetoric of indigenism in Brazil”. Critique of Anthropology, Thousands Oaks. 11 (2): 155-169.

. 1995. “O índio hiper-real”. Revista Brasileira de Ciências Sociais. 28 (10): $5-14$.

1998. Indigenism: ethnic politics in Brazil. Madison: Univ. of Wisconsin Press.

ROCHA, Everardo Guimarães. 1984. O que é Etnocentrismo. São Paulo: Ed. Brasiliense.

SCHWADE, Egydio. 1992. "Waimiri-Atroari: a história contemporânea e um povo na Amazônia”. In: HOORNAERT, E. (Org.). História da Igreja na Amazônia. Petrópolis: Vozes, pp. 366-392.

SILVA, Carmen Lucia da. 1998. Sobreviventes do Extermínio. Uma Etnografia das Narrativas e Lembranças da Sociedade Xetá. Tese de Mestrado, Universidade Federal de Santa Catarina.

STAUFFER, David Hall. 1959. “Origem e fundação do Serviço de Proteção aos Índios”. Revista de História. 18 (37): 73-96.

TRINIDAD, Carlos Benítez. 2015. "La dimensión indígena del salvaje europeo”. Historia 2.0. Conocimiento histórico en clave digital. 9: 31-50.

. 2016. "La Fundação Nacional do Índio al servicio de los intereses geoestratégicos e ideológicos de la dictadura brasileña (1967-1985)”. Americanía: Revista de Estudios Latinoamericanos. 3: 243-277.

2016. "La oposición necesaria al desarrollo moderno en Brasil: el indio y la dictadura”. Iberoamérica Social: revista-red de estudios sociales. Especial (1): 25-48.

\section{Documentação}

Acervo Armazém da Memória. Disponível em: <http: / / armazemmemoria. com.br/ $>$.

- ACONTECEU ESPECIAL, 1982, p. 86

- JORNAL DO BRASIL, 27 de agosto de 1972

- JORNAL DO BRASIL, 23 de março 1973

- JORNAL DO BRASIL, 23 de março 1973

Acervo Museu do Índio. Disponível em: <http: / /www.museudoindio.gov. 
$\mathrm{br} /$ pesquisa/acervo-online> .

- FUNAI, Boletim Museu do Índio, etnohistoria n.1, maio/1979

Acervo O Globo. Disponível em: < http://acervo.oglobo.globo.com/>.

- 09 de abril 1981

- 1 de julho 1973

- 14 de setembro de 1973

Acervo O Estado de São Paulo. Disponível em: <http:/ /acervo.estadao.com. $\mathrm{br} />$.

- 22 de maio 1971

- 26 de abril 1972

- 14 de agosto 1973

- 1 de março 1975

- 24 de fevereiro 1976

Acervo Veja. Disponível em: <http://veja.abril.com.br/complemento/acervodigital/index-novo-acervo.html>

- 15 de abril 1970

- 25 de maio 1971

Arquivo Nacional - Memórias Reveladas. Disponível em: <http://www. memoriasreveladas.gov.br>.

- Centro de Informação e Segurança da Aeronáutica - CISA

Biblioteca FUNAI - Curt Nimuendajú. Disponível em: <http://biblioteca. funai.gov.br>.

- PORANTIM, setembro 1980

- PORANTIM, 1979

Câmara dos Deputados. Relación de notas taquigráficas del archivo digital, Disponível em: <http://www2.camara.leg.br/documentos-e-pesquisa/arquivo>.

- 11 de março de 1965, p. 681

- 28 de maio 1946, p. 2133

- 23 de março 1962, p. 194-195

- 11 de junho 1968 , p. 3361

COMISSÃO NACIONAL DA VERDADE (CNV no texto). 2014. Relatório: textos temáticos, v. 2. Disponível em: <http://www.cnv.gov.br/>.

SILVA, Luiz Fernando Villares e. (Org.). Coletânea da legislação indigenista brasileira. - Brasília: CGDTI/FUNAI, 2008.

- Lei no 5.371, 5 de dezembro 1967 
Resumo: Neste artigo pretende-se dar espaço à reflexão sobre o conceito de alteridade. Estabelecendo um paralelismo entre o imaginar e o dominar, almeja-se refletir sobre como antes de impor o domínio sobre o Outro, na luta pela hegemonia no contexto colonial/nacional como é o brasileiro, primeiro há que percebê-lo ontologicamente como merecedor desse domínio, pensamento que contém uma forte dose de violência. Para isso vai se utilizar o contexto da questão indígena durante a ditadura civil-militar, já que oferece um marco de trabalho interessante para a abordagem da reflexão. Mostra-se, ao final, como desde o poder político/econômico e a tensão do contato interétnico, houve uma lógica de desumanização do índio, que legitimou uma práxis predadora sobre os povos indígenas. A metodologia usada segue os passos da imprensa do momento, assim como os discursos políticos, depoimentos e relatórios.

Palavras chave: Ditadura, Brasil, "Índio", Alteridade, Hegemonia, Desumanização.
Abstract: The present paper aims to think about the otherness as a concept. Establishing a parallelism between imagination and domination, this exposition intends to reflect about how before to impose the dominion upon the otherness, in the fight for hegemony in a colonial/national context as is Brazil, first it is needed to imagine that it deserve ontologically the dominion, way of thinking that has some strong doses of violence. For that reason, this research was made about the indigenous issue in the dictatorship context, because it offers optimal framework for this reflection. By the end, we can see how from the political/economical powers and the interethnical conflict there were dehumanization logic about the indigenous, something that legitimizes a praxis of predation upon the natives population. The used methodology follows the steps of the national media, also the political speeches, testimonies and reports.

Keywords: Dictatorship, Brazil, Indian, Otherness, Hegemony, Des-humanization 